\title{
The Advantages of Comparative Codicology: Further Examples
}

\begin{abstract}
The sharing of basic anatomy, techniques and scribal practices of codex production that embodied in manuscripts produced in all the codex civilisations warrants implementing a comparative perspective in our research and in determining the codicological typology of each of the script cultures of the codex. Yet, comparative codicology does not have to be confined to the codex cultures and should attempt to unveil affinities to the production of non-codex manuscripts, as one sample demonstrates. Comparative codicology should indeed be expanded and be universal.
\end{abstract}

\section{Introduction}

Some thirty years ago, I published a short article devoted to the benefits of comparative codicology to scholarship and research. ${ }^{1}$ My findings were based on the observation that practices of book production were imprinted by a shared tradition ingrained in all cultures in which the codex served as a receptacle for texts and a means for their preservation and dissemination, regardless of the variety of languages and scripts. One may marvel at the force of the regularity and continuity revealed in the basic structures, production techniques, social, artisanal and intellectual functions, and the aesthetic principles embodied in mid- and late medieval codices throughout book civilisations in all cultures. Be they codices inscribed in Latin, Greek, Arabic, Persian or Hebrew scripts, or in the less widespread Syriac, Coptic, Glagolitic and Cyrillic scripts - they all partake of the very same anatomy of the codex: common writing materials, similar proportions and formats, the analogous molecular structure of quiring achieved by the folding and stitching together of a regular number of bifolia, and the use of various means of markings in the margins ensuring the correct order of quires and bifolia. The great majority of these codices would be set for copying by the laying out of the writing surface and by its ruling in a variety of techniques, most of them shared, functioning as a scaffold for the writing. All made use of

1 Beit-Arié 1993b. See now Beit-Arié 2020.

Ә Open Access. (C) 2021 Malachi Beit-Arié, published by De Gruyter. (๕) BY-Nc-ND This work is licensed under the Creative Commons Attribution-NonCommercial-NoDerivatives 4.0 International License. https://doi.org/10.1515/9783110753301-020 
additional para-scriptural and peri-textual graphic means for improving the readability of the copied text and for achieving its transparent hierarchy. Some would include illustrations, ornamentation and illuminations in the margins or within the body of the copied text. Although the manifestations of this common infrastructure underwent changes over time, as for example the composition of quires, the ruling techniques, and the text's disposition on the page, this structure also displayed, throughout its permutations, a stability and continuity which lasted close to a millennium, allowing us to regard it as some kind of universal grammar that permeated, in some elusive ways, all codex civilisations. Furthermore, its imprint can still be recognised even after the invention of the mechanical printing press, which, notwithstanding its revolutionary nature, still embodies patterns inherited from the deep structure of the manually produced codex. In truth, the basic book form survived very much into our own times, despite the paradoxical resurrection of the form of the vertical scroll - the rotulus - on computer displays.

The existence of a common basic tradition of codex production warrants, therefore, that we integrate a comparative perspective and rely on it in our research and in determining the codicological typology of each of the script cultures, calling even for the establishment of a general comparative codicology. All the more crucial is the reliance on a comparative perspective in the study of Hebrew manuscripts and in establishing their historical typology. ${ }^{2}$ This need is an outcome of the wide dispersal of Hebrew manuscript production in the zones of the codex civilisations around the Mediterranean and in adjacent regions to its north and east. ${ }^{3}$

2 The indispensability of the comparative approach and the rewards of implementing it were first emphasised in Beit-Arié 1981. This emphasis is reflected also in the subtitle of Beit-Arié 1993a (Towards a Comparative Codicology) and presented there pp. 99-103. There I remarked that Hebrew manuscripts, by bridging between East and West and between Islam and Christianity, may serve as a productive medium for comparative research. Indeed, in recent years awareness of the importance of the comparative aspects of bookcraft has been spreading within European codicology as well. This is evident in the collection published in 1998 (Hoffmann 1998), which brought together articles presenting data on the material characteristics of Latin, Greek, Arabic, Persian, Hebrew, Syriac, and Armenian manuscripts.

3 No doubt, this dispersal and concomitant distribution of script types of the Hebrew codex render the comparisons between Hebrew bookcraft and design and those of the host societies of vital importance for the understanding of the unique typology of the Hebrew book in each of its different diasporas, and for the identification of its sources of inspiration and affinities. Indeed, despite the shared script and, in most copied and designed books, the shared use of the Hebrew alphabet, and despite the strong religious cohesion and social solidarity, the affinity of Hebrew codices with one another is often lesser than that which existed with non-Hebrew 
In my 1993 article, I included a few illustrations demonstrating the advantage of using comparative codicology in our research. I argue that the comparative method contributes not only to the study of one given manuscript culture but should also infer upon the collated cultures. The said article cites as an example what could be an explanation for the long delayed adoption of plummet ruling by Hebrew scribes in North-Western Europe (particularly in Franco-German lands), which also required a shift in the ruling technique. The unexplained belated adoption of the coloured metallic instrument that replaced the economical blind relief ruling by hard point (which prevailed in all the codex civilisations until the late eleventh century) has been elucidated once a comparative search was applied. It could have hardly been a coincidence that the shift to plummet by Latin copyists overlapped with the early stage of development of the layout of the glossed Bibles from the early twelfth century. Were literary requirements of Hebrew texts similar?

Indeed, a quantitative decline of original Hebrew literary creation during the thirteenth century, coinciding with a proliferation of the anthological genre - namely, annotated texts embedded with glosses, which peaked at the end of the century - required an adjustment of the ruling technique. From the second half of the thirteenth century onwards, especially in Germany and Northern France, the Hebrew book scene saw the evolution of several textual genres (especially commented biblical and halakhic [legal] codices) of complex structure, which integrated, merged, or linked multiple layers of texts, or combined a core text with commentaries, annotations, and glosses. A uniform delineation and regular ruling patterns were unsuited to the scribe's (and author's) attempt to achieve structural transparency for the entirety of the copied texts through visual and graphic means. To reflect the layers' relations one to another and especially to the core text, these texts would deploy several modes of script of

codices produced by host societies. Spain (and after the Christian reconquista also Christian Spain) and North Africa were greatly affected by Arabic calligraphy but less so by Arabic bookmaking; on the other hand, the codicological features, design and scripts of Hebrew manuscripts produced in France and Germany were definitely marked by Latin manuscripts produced in their respective environments, yet this was less so in Hebrew manuscripts produced in Italy until the fifteenth century, Beit-Arié 2002, 377-396.

Employing a comparative perspective in these regards may enable us not only to deepen our understanding of transformations in the practices of bookmaking in the various zones, but also help elucidate an issue much debated by historians, who diverge in their assessments as to the degree of acculturation and integration of the environment's ways and customs by the Jewish society, or the degree of reclusion of these persecuted and rejected minorities, which were yet embedded within gentile societies. 
different sizes and densities. Such layered copying required frequent adjustments of the ruling pattern. Layered and glossed texts thus pertain to the practice of dynamic copying, as their layout would be redesigned for each page. As the structures and layouts of the commentated biblical texts and of the widespread halakhic corpora necessitated a flexible and dynamic form of ruling, they prompted the adoption of the plummet, which had been avoided by Hebrew scribes during a long period. My arguments that practices of book production are imprinted by a shared tradition in all cultures were confined to cultures whose book form was the codex. It had not occurred to me that some codicological practices can be traced in non-codex manuscripts as well. I would therefore add another two demonstrations in the comparative study of manuscripts, one of them pertaining to a codicological practice shared by Oriental and Occidental codices, while the other relates to a Chinese bamboo manuscript and its affinity to Oriental and Occidental codicological practices.

\section{Positioning of parchment bifolia in quiring}

Quires made of parchment with distinguishable sides were structured and ordered methodically and consistently by matching the bifolia sides and the openings of the codex. The conspicuous difference of the texture, or at least the hue, of the parchment sides led to a wide acceptance of the practice in all civilisations of the codex, at least from the tenth century and on, of arranging the quire's bifolia by matching their sides prior to folding: hair side facing hair side and flesh side facing flesh side. Consequently, we find that the two pages showing in each quire opening, each belonging to a different bifolium (except for the ones in the central opening of each quire), are identical in appearance - alternating hair sides and flesh sides. As a result, one can easily discern if a folio is missing: for when the matching of the sides is disrupted and an opening displays two different sides of the parchment facing each other, we may conjecture that a folio (or an odd number of folios) is lacking.

Astonishingly, this practice, which had been current since the tenth century or before throughout all zones and all types of bookcraft, was noticed only in late-nineteenth century. It had been named 'Gregory's rule', after the scholar of Greek manuscripts who publicized it. ${ }^{4}$ The guiding principle behind this symmetrical arrangement seems to have been aesthetic. However, a parchment

4 Gregory 1885, 264-265. 
maker in Rotterdam engaged in the history of parchment making, Henk de Groot, recently claimed convincingly (as in his email sent to me dated 9 July 2015) that the bifolia leaves were arranged by corresponding sides in view of the concavity of hair sides and the convexity of flesh sides. Disposing the folios according to opposite arcs (concavity facing concavity and convexity facing convexity) neutralizes the curvature and is therefore crucial in the production of a codex as a tight block, whether closed or open and leafed through. The aesthetic aspect was, so it seems, an outcome of the codicological requirement. To quote de Groot's extraordinary statement:

I think the manuscript makers choose the parchments leaves in opposite bowing to neutralize the bowing of the leaves together. The result: a flat manuscript block. The equal colour of the openings was a lucky gift of beauty.

( ) ( ) ( ) gives: IIIIII

( ( ( ( ( gives: $)(((()$

It has been argued that this regularity was an outcome of constructing the quire by means of folding an entire parchment sheet. The scant number of early Latin codices in which quires were constructed by folding, as well as the quire structure in some of the earliest Greek and Latin codices showing an odd number of bifolia dispute this view. The order of the bifolia's sides in the quire would usually be marked by the initials representing the flesh or hair side on every recto side in the first half of the quire, e.g. HFHFH (for a quire made of five bifolia beginning with the hair side, with the openings alternately matching).

It appears that Gregory's rule, displayed in every quire of all dated Hebrew codices, had not been observed in some of the early-undated manuscripts, although they too show a regular arrangement. In Geniza fragments and even in a few complete codices, all apparently from the region of Iraq, it so happens that the spread out bifolia were arranged with the hair (or flesh) facing regularly a uniform direction; in other words, after folding, the sides did not match at each opening (except for the centre opening). Instead, flesh sides would face hair sides. ${ }^{5}$ The assumption that this practice was typical of Babylonian Hebrew manuscripts (produced in Mesopotamia, ancient Iraq) ${ }^{6}$ is undermined by the data concerning this method of arrangement in early Oriental and Occidental manuscripts inscribed in other scripts - Latin, Syriac, and Arabic.

5 HHHHH (in quinions, as practised in the Orient), as in Vatican, BAV, Vat. ebr. 66, the early Sifra manuscript with Babylonian vocalization, see Glatzer 1995, 19-24.

6 See Glatzer 1995. 
The methodical arrangement with non-matching sides is attested also in Latin Insular manuscripts (produced on the British Isles) from the second half of the sixth century until around 700 (and later also from the ninth century till the eleventh); as well as in manuscripts produced in scriptoria on the continent, especially under the influence of Insular bookcraft. ${ }^{7}$ Julian Brown maintained that this quiring practice in early Insular manuscripts (which quiring by quinions may attest to Oriental influence) was affected by papyrus codices. ${ }^{8}$ According to Sebastian Brock, Gregory's Rule had not been maintained in early Syriac manuscripts produced in both the eastern and western parts of the Middle East. ${ }^{9}$ The arrangement of bifolia with non-matching sides, namely in the HHHHH pattern (as in those Hebrew manuscripts), was the standard arrangement in Syriac manuscripts produced in the scriptoria of Syriac monasteries of both the Eastern Church, known as the Nestorian Church, and the Western Church, known as the Jacobite or Syriac Orthodox Church. ${ }^{10}$ Moreover, in a large sample of fragmented Arabic manuscripts of the Qur'an from the end of the seventh century through the middle of the tenth century it appears that most of the bifolia were arranged with non-matching sides (HHHHH). ${ }^{11}$ Consequently, it seems that the method of constructing quire bifolia disregarding the matching of parchment sides was not zone- but time related; moreover, it could well be that all early codices in all scripts were arranged at first according to this method, imitating the papyrus codex, and that at some point (which might have been different for each region or script) bifolia came to be arranged with matching sides. Babylonian Hebrew scribes might have continued to practice the old

7 Vezin 1978, 26-27.

8 Julian Brown refers to the sheets of papyrus that were cut into bifolia, formed by strips taken from the stem of the reed, and were manufactured in two layers so that the strips of one layer were perpendicular to those of the second layer and thus they were pressed and forged together. When arranging the bifolia that had been cut from papyrus sheets, they would be laid out in such a manner that in each of the codex's openings one side displayed horizontal strips of fibre while the opposite side displayed vertical strips. Brown believes that quiring by non-matching sides in Insular manuscripts was influenced by the practice found in early Continental and Oriental manuscripts: as parchment started to be used, scribes who were not practised in the folding of sheets were likely to create their parchment quires as was done in papyrus codices, see Brown 1984, 234-235.

9 His view was put forward in an unpublished paper, which I thank him for letting me read: P.S. Brock, 'Saba, the Scribe "who never made a blotted tau" - Some Codicological Notes on Three Syriac Manuscripts from Redsh'aim, ca. A.D. 724-726'.

10 Briquel-Chatonnet 1988, 158-159.

11 See Déroche 2005, 71-76. Déroche 2005, 83-85, proposes that this practice imitates the papyrus codex, as Brown had already proposed before him. 
method for some time even after Jewish scribes in other areas had adopted the new one.

\section{Chinese Bamboo Manuscripts}

Bamboo (or wood) slips were the main book form for writing manuscripts in preimperial and early imperial China before the widespread introduction of paper during the CE's first two centuries. ${ }^{12}$ The long, narrow strips of bamboo were tied together and connected by binding strings. The custom of interring books made of the durable bamboo strips in royal tombs preserved many works in their original form for centuries. Large collections of bamboo-slip manuscripts were excavated and discovered since the early twentieth century.

One of the basic problems facing researchers who deal with early Chinese bamboo or wood manuscripts is the disintegration of the excavated slips. The binding strings that had been originally holding together the slips constituting a manuscript - either vanished or remained as traces only on individual slips. The problem of reconstruction becomes even more complex if the manuscript in question was not scientifically excavated. Since 2011, the phenomenon of carved lines (sometimes drawn in ink or by brush) on the recto side of slips has been observed and studied, particularly by Thies Staack, a student of Michael Friedrich, who was a supervisor of his dissertation. Staack surveyed and clarified the finds of lines on the slips' verso and emphasised that continual verso lines were mainly found to have related to the written recto of the original sequence of the slips. Consequently, the continuous forms of the lines serve as a fundamental key for the textual reconstruction of the bamboo manuscripts. Staack extended the application of the European (and Middle Eastern) codicological terminology while dealing and interpreting the function of the verso lines, borrowing the term 'codicological unit' for a sequence of the slips, and suggesting that the sets of slips in bamboo manuscripts are roughly comparable to the quire of codex manuscripts.

For the codex-codicologist, the functional similarity of the practice of continuous lines carved on the back side of bamboo slips to the quiring of Western and Near Eastern codices is indeed striking. Moreover, the Ancient Chinese practice

12 The information is completely drawn from the following publications: Staack 2015, 2016 and 2017. 
shows affinity to European codicological means meant to ensure the right order of the bifolia or folios within the quire and marking their sequence after copying, and all the more so during the copying process. The means employed by Latin and Jewish copyists to ensure the correct binding of the codex can be classified into two main groups: methods based on catchwords drawn from the copied text, ${ }^{13}$ and methods based on numbering that was added to the text at its material. Both systems were implemented at the codicological dividing points of the codex structure - initially only at the transition from one quire to the next, and eventually also in transitions between bifolia within the quire and even between the manuscript's folios, although these are not independent codicological units. In all zones of production of Hebrew codices both methods were used, usually simultaneously in the same manuscript, but in the numbering methods were extremely rare, and even in Byzantium they were scarcely used. Generally, the methods used to ensure the order of the codex in paper manuscripts were different from those used in parchment manuscripts, except in the Middle East, where paper replaced parchment as the standard writing material already in the beginning of the eleventh century. In the other zones, where paper spread only much later, paper was presumably deemed more vulnerable than parchment and its folios more likely to be separated from their pairing and to become detached from their quire. For this reason copyists were not satisfied with only preserving the order of the quires, like most copyists of parchment manuscripts, but added more means to ensure the order of bifolia and folios. ${ }^{14}$ It can hence be inferred that these means spread in those areas in later periods. Acquaintance with these methods ${ }^{15}$ has clear typological but also chronological

13 An unusual method of using graphic markings instead of catchwords was employed in an undated fifteenth-century manuscript in an Ashkenazic script (New York, Jewish Theological Seminary of America, L873). A number of forms were marked at the bottom of each verso page and were repeated on the following recto pages.

14 This explanation for the proliferation of means of ensuring the order of bifolia in the more vulnerable paper codices can be contested: without temporary stitches, the order of parchment bifolium copying could be also easily disrupted during the copying process.

15 The development of means for ensuring the order of the Hebrew codex, until they came to be implemented on every single folio - even on every single page - was presumably not only precipitated by the transition to writing on paper but was also (and perhaps primarily) due to the relatively late development of indexing and inscription of a table of contents in Hebrew books, and naturally these required a precise marking of text locations. Probably the earliest evidence for the inscription of a table of contents appears in the prologue of Rabbi Eliezer ben Natan (one of the early Tosaphists from Germany, deceased 1170) to his work Even ha'ezer. Another important reference is the hierarchical detailing of the names of the chapters (halakhot) in each book of Maimonides' Mishne Tora. 
value. The prevalence of each type may help us date a manuscript and to some degree identify its provenance as well. What's more: understanding these methods provides a vital key to uncovering the structure of the quires when invisible, especially in paper manuscripts, and reconstructing the folios, the bifolia, and even the missing quires of a codex.

In conclusion, the partaking of functional means for ensuring the continual order of the copied text in manuscripts is shared not only by different codex production traditions in areas around the Mediterranean but also by preimperial and early imperial China bamboo slips manuscripts. Comparative codicology must not be confined to the codex civilisations and should attempt to unveil affinities to the production of non-codex manuscripts. Comparative codicology should indeed be expanded and become universal.

\section{Acknowledgements}

It is my honour to participate in a festschrift dedicated to Professor Michael Friedrich, a pioneering scholar who initiated, established and expanded the unique Centre for the Study of Manuscript Cultures. Thanks to his vision and inventiveness, material manuscript studies are now diffused and manifest in numerous cultures and countries and the comparative approach has been boosted.

\section{References}

Beit-Arié, Malachi (1981), Hebrew Codicology: Tentative Typology of Technical Practices Employed in Hebrew Dated Medieval Manuscripts, Jerusalem: The Israel Academy of Sciences and Humanities [reprint with addenda and corrigenda, first publication Paris: Institut de Recherches et d'Histoire des Textes, 1977].

Beit-Arié, Malachi (1993a), Hebrew Manuscripts of East and West: Towards a Comparative Codicology (The Panizzi Lectures, 1992), London: British Library.

Beit-Arié, Malachi (1993b), 'Why Comparative Codicology?’, Gazette du livre médiéval, 23: 1-5.

Beit-Arié, Malachi (2002), 'Towards a Comparative Typology of Italian Hebrew and Latin Codices', in Francesco Magistrale, Corinna Drago and Paolo Fioretti (eds), Libri, documenti, epigrafi medievali: Possibilità di studi comparativi. Atti del Convegno internazionale di studio dell'Associazione Italiana dei Paleografi e Diplomatisti, Bari (2-5 ottobre 2000), Spoleto: Centro Italiano di Studi sull'Alto Medioevo, 377-396.

Beit-Arié, Malachi (2020), 'Comparative codicology', in Frank T. Coulson and Robert G. Babcock (eds), The Oxford Handbook of Latin Palaeography, Oxford: Oxford University Press, 669-673.

Briquel-Chatonnet, Françoise (1998), 'Cahiers et signatures dans les manuscrits syriaques. Remarques sur les manuscrits de la Bibliothèque nationale de France’, in Hoffmann (ed.) 1998, 153-169. 
Brown, Julian (1984), 'The Oldest Irish Manuscripts and their Late Antique Background', in Próinséas Ní Chantháin and Michael Richter (eds), Irland und Europa, die Kirche im Frühmittelalter / Ireland and Europe: The Early Church, Stuttgart: Klett-Cotta, 311-327 [collected in Janet Bately, Michelle Brown and Jane Roberts (eds), A Palaeographer's View: Selected Writings of Julian Brown, London: Harvey Miller, 1993, 221-244].

Déroche, François (2005), in collaboration with Annie Berthier et al., Islamic Codicology: An Introduction to the Study of Manuscripts in Arabic Script [transl. Deke Dusinberre and David Radzinowicz, ed. Muhammad Isa Waley], London: Al-Furqan Islamic Heritage Foundation.

Glatzer, Mordechai (1995), 'Early Babylonian Hebrew Manuscripts', Gazette du livre médiéval, 27: 19-24.

Gregory, Gaspar René (1885), 'Les cahiers des manuscrits grecs', Comptes rendus des séances de l'Académie des Inscriptions et Belles-Lettres, 29/3 : 261-268.

Hoffmann, Philippe (ed) (1998), Recherches de codicologie comparée. La composition du codex au Moyen Âge en Orient et en Occident, Paris: Presses de l'École normale supérieure.

Vezin, Jean (1978), 'La réalisation matérielle des manuscrits latins pendant le haut Moyen Âge', in Albert Gruys and Johan P. Gumbert (eds), Codicologica, 2: Éléments pour une codicologie comparée, Leiden: Brill, 15-51.

Staack, Thies (2015), 'Identifying Codicological Sub-units in Bamboo Manuscripts Verso Lines Revisited', manuscript cultures, 8: 157-186.

Staack, Thies (2016), 'Reconstruction of Early Chinese Bamboo and Wood Manuscripts: A Review (1900-2010)', <https://www.csmc.uni-hamburg.de/publications/occasionalpapers.html\#14662914> (accessed on 2 Feb. 2021).

Staack, Thies (2017), “The Neglected “Backyard” of Early Chinese Manuscripts: How an Analysis of the Verso of Bamboo Slips can enable the Reconstruction of a Manuscript Roll', <doi.org/10.11588/heidok.00023213〉. 